\title{
Experimental research on the effects of Information and Communication Technology (ICT) in the instructive-educational process
}

\author{
Elena Mădălina DEDU \\ The Bucharest University of Economic Studies, Bucharest, Romania \\ madalinnad@yahoo.com \\ Alecxandrina DEACONU \\ The Bucharest University of Economic Studies, Bucharest, Romania \\ alecxandrinadeaconu@gmail.com \\ Lavinia RAȘCĂ \\ The Institute for Business Administration in Bucharest, Romania \\ laviniar@asebuss.ro
}

\begin{abstract}
This research aims to highlight the efficacy of the use of Information and Communication Technology as a didactic teaching, learning and evaluation method for improving the instructionaleducational process within the tourism high school. Our research, which took place in 12 high schools with classes in Tourism and Nutrition in the County of Constanta between 2013 and 2016, was based on two variables: the independent variable - represented by the continuous, systematic use of ICT methods in teaching and learning content at the disciplines included in the curriculum Tourism and Nutrition at different levels of study and the dependent variable - which depends and changes according to the independent variable: the specific skills, the degree of understanding and assimilation of the specialized contents. In this article we will present the experimental phase in which the actual research was carried out on two parallel groups of subjects: an experimental group (where ICT methods were used - the coordinating teachers created virtual classes on the educational platform www.easyclass.com) and a control group (in which classical didactic methods were used) and the postexperimental phase in which tests of knowledge assessment were applied to both the experimental classes and the control classes. The post-experimental step allowed the measurement of the dependent variable in the two samples of subjects, experimental and control, and the comparison of the initial data with the final ones. For this purpose, tests for assessing the knowledge acquired by the pupils in the experimental and control classes as a result of each unit of learning included in the content sample were applied. These tests were created depending on the specific and derived competences of each unit of learning, following the extent of their development at the pupils in the two samples.
\end{abstract}

Keywords: Information and Communication Technology, experiment, educational process, vocational education, tourism, young people.

\section{Introduction}

The constant desire to discover new ways to attract young people to school subjects, to find ways to transfer knowledge as pleasantly as possible, or ways to design new tools to assess their evolution as a result of attending classes has led to the continuous diversification of the teaching-learning-evaluation methods used in the instructive-educational process. 
The didactic methods have gradually evolved from the classical to the modern ones, and nowadays it is being used very much the Information and Communication Technology in the instructive-educational process.

Most specialists believe that we should not ask ourselves whether training is improved by using computers, but how we can use better the unique qualities of computers that differentiate them from other environments. The unique qualities of this environment are: the computer interactivity; the accuracy of the operations performed; the ability to provide multiple and dynamic representations of phenomena; meaningful and differentiated interaction with each student.

At the level of the pre-university education system, the two key actors of the teaching process, the teacher and the group of pupils, share the responsibilities and benefits of using the new technologies.

The introduction of ICT in educational activity has a powerful influence on didactic strategies and on the forms of learning organization, the learning act transforming from an activity based on the teacher's intervention into one based on the interaction of the students with the teacher, with the computer and sources of information.

\section{The usage of ICT in education}

Different stakeholders in society (authorities, parents, business community, pupils, students etc.) are increasingly urging the education sector to consider integrating Information and Communication Technology (ICT) into the classroom, taking into account the rapid process of transforming the society into a knowledge-based society in which the use of technology has become a core competence. (Mocanu (Dedu), Deaconu, 2017).

Being an important aspect of modern life, Information and Communication Technology can greatly support the revival of the learning process, but teaching methods do not automatically improve due to ICT implementation in the classroom. It is necessary for ICT to be incorporated into the instructive - educational process in a careful, balanced way, the benefits of ICT being achieved especially when attention is paid to the entire educational environment and not only to technology as a medium for the transmission of information. (Vandenbroucke, 2007-2009).

The development of the technology has led to its widespread use in all fields, the young being its main users. Therefore, high school students are more receptive to information transmitted through IT tools than through classical methods, assimilating knowledge more easily for longer periods, and forming the specific skills needed to integrate into the labor market.

At the same time, teachers have to deal with the multitude of information, they have to know and to use the new means of access to knowledge, new forms of collaboration and networking cooperation, to master the lifelong learning model. In other words, in order to meet the demands of the knowledge society, teachers have to develop new specific competencies. (WCCE, 2005).

The increasing use of ICT in teaching and learning processes does not, however, reduce the status of teacher's key agent in the educational system, according to Brezeanu and Gorghiu (2012) that state that "the newer technology be, the more teachers has to be better, and the training - of quality". 
Improving the quality of education and training is a major issue at a time of expansion in education and Information and Communication Technology can also successfully contribute in solving this problem through different ways: increasing motivation and commitment of learners, facilitating the acquisition of basic skills and enhancing teacher education. (Mocanu (Dedu), Deaconu, 2017; Ghinea et al., 2017).

The motivation of learners has become a major concern for educators. (Radu, 2014). The various technologies that combine text, sound, color, moving images can be used to provide authentic and interesting materials designed to attract and involve young people actively in the learning process. The various technologies that combine text, sound, color, moving images can be used to provide authentic and interesting materials designed to attract and involve young people actively in the learning process. (Tinio, 2003)

The terms in which the relationship between the teacher and the pupils is configured today are very different from what happened more than a decade ago. In order to assume the new roles, the teacher needs, in addition to digital literacy, the development of advanced ICT skills (Hadad, 2017).

Through new information and communication technologies, the education system can help achieve the four basic elements of the knowledge-based society.

Know-who - information about who is doing and what he can do.

In the work Motivating Students - How Great Teachers Should Be? (Radu, 2016) the author identified, based on a questionnaire applied to learners, the main characteristics: (Government of Romania, Ministry of Communications and Information Society, 2012)

Know-what - representing information, factual knowledge about reality, contributing to its explanation;

Know-why - refers to the understanding of reality based on the scientific knowledge of the laws and principles of nature;

Know-how - development of skills and abilities to apply in practice different knowledge, information, principles of operation;

Students appreciate the use of special teaching methods such as interactive methods, applied methods, games, real-life simulation, case studies, etc. Information and Communication Technology provides teachers and pupils with a wealth of tools that facilitate interaction and collaboration among users, communication, application of theoretical notions in practice, development of creativity, problem solving, critical thinking development etc.

Debates between supporters of new technologies state that Web 2.0 applications have a tremendous potential for transforming student learning. However, although Web 2.0 tools such as Facebook, MySpace, wikis and blogs are part of the private life of any student, these technologies are rarely used in school. (Constantin \& Dinică, 2006)

Interested in the evolution of the tourism industry in Romania, to the development of which the human resources employed contribute decisively, we have carried out a broad analysis of the current situation and we have identified the role of a well-trained workforce in the field of tourism. The education and training of future employees is a decisive factor in the development of tourism and in the provision of quality tourism services, and these are carried out within the secondary education and training institutions, respectively in the high schools of Tourism and alimentation. It is also of great importance to identify the 
effective methods and means by which the future workforce in tourism can be educated and trained to become capable of performance in the workplace.

As a result of the documentation from the literature we found the lack of previous research on the use of ICT methods in high school tourism education in our country and therefore we considered it appropriate to carry out a research on the necessity and efficacy of the use of ICT tools in the educational process at the pre-university level, in high schools with classes of Tourism and food profile.

The research was conducted within 12 high schools with Tourism and alimentation classes in Constanta County. We chose this area for analysis because Constanta County is an important tourist area of Romania and a large part of those who work in Constanta tourism are graduates of high schools in the region, prepared in accordance with the needs of employers.

\section{General coordinates of research}

The aim of the research was to highlight the efficacy of the use of ICT as a didactic teaching, learning and evaluation method for improving the instructional-educational process within the tourism high schools.

In order to achieve the research goal, we have pursued the following objectives:

- Developing the specific skills to the fullest extent by using ICT methods;

- Expanding the knowledge assimilated by students within the hours of tourism;

- Improving school performance in specialized disciplines measured by the results to school contests;

- Increasing student motivation for active participation in tourism lessons;

- Reducing absenteeism at tourism classes.

The following hypotheses were formulated for the realization of the research:

H1: The specific competencies that students form and develop by using ICT in tourism classes are superior to those obtained through the use of classical didactic methods;

H2: The use of ICT as a teaching method during tourism lessons leads to significant improvements in the degree of understanding and conscious assimilation of specialized knowledge.

The variables used in the research are:

- Independent variable - represented by the continuous, systematic use of ICT methods in teaching and learning content at the disciplines included in the curriculum Tourism and alimentation at different levels of study;

- Dependent variables - which depend and vary depending on the independent variable: specific skills, degree of understanding and assimilation of specific content.

The research was conducted during three school years (2013-2014, 2014-2015 and 2015-2016) in 12 tourism high schools in Constanta County. As a result of the previous studies, we have noticed that in Constanta County there are a large number of high school units that prepare the human resources necessary for the tourist sector, in accordance with the needs of tourism employers. The pre-experimental stage of the research was attended by 50 teachers and 948 students and the experimental stage was attended by 4 teachers and 472 pupils.

The main method used in the research is the psycho-pedagogical experiment consisting in the formation of two samples of subjects, respectively the experimental 
sample and the control sample, the modification of the pedagogical phenomenon studied by applying the independent variable on the experimental sample and analyzing the evolution of the dependent variables by comparison with the control sample. In the present research, the experiment consisted in the use of the ICT tools as didactic methods (the independent variable) and the study of the modification of the dependent variables by comparison with the control classes that used classical didactic methods.

PICBE $\mid 292$

The t-Test statistical tool (Microsoft Excel) was used to analyze the effects of an independent variable on multiple dependent variables by comparing the results associated with the two levels of the independent variable (use and non-use of ICT in the educational process).

The development of this research consisted of four stages of the pedagogical experiment listed below and presented in the following chapters.

a) The pre-experimental stage is the stage where the existing level of the dependent variables (specific competences and degree of understanding and assimilation of the specialized contents) is established at the time of initiation of the experiment, measuring their level on both groups (experimental and control) by applying the same pretest.

b) Experimental stage is the stage where the independent variable (the continuous, systematic use of ICT methods) is introduced into the experimental group, while the control groups are working the same as before. At this stage the actual experiment takes place, that is, teachers transmit the knowledge to the students from the experimental classes using different ICT methods.

c) The post-experimental stage is the third step consisting of measuring the dependent variable in both groups by applying the posttest. By using similar samples, the initial data are compared with the final ones, the differences obtained are established, and the assumptions of the research are confirmed or invalidated;

d) Stage of retesting is the stage in which the solidity, durability of the effects produced by the experiment is assessed after a period, by applying the retest.

In this article we chose to present two stages of the research, namely the experimental stage and the post-experimental stage.

\section{Experimental stage}

At this stage, the actual experiment was carried out, which consisted in transmitting to the subjects participating in the research the knowledge from the established content sample, by using different methods.

In the experimental classes were used methods based on Information and Communication Technology, and in the control classes were used traditional and modern teaching methods.

Following the completion of each unit of learning included in the content sample, teachers applied the knowledge assessment tests to both the experimental classes and the control classes whose results were the basis for the later stage interpretations.

The educational process in the control classes was carried out by using classical and modern didactic methods in the teaching and learning activities included in the content sample. Thus, teaching and learning have been achieved through communication methods (explanation, description, conversation, training, questioning, etc.), exploration methods 
(observation, case study, etc.), methods of action (exercise, role play) and the use of interactive methods.

The activities from the experimental classes were carried out by introducing the independent variable, respectively by using the ICT methods in teaching and learning the specified contents. For all experimental classes, virtual classes were created on the www.easyclass.com educational platform by coordinating teachers. Also, ICT tools have been introduced at the different moments of the lessons, namely for the transmission, fixation, consolidation and evaluation of knowledge.

Activities have been carried out by teachers who usually teach to the experimental and control classes and who frequently use new technologies in the educational process. The lessons were of different types, aiming at achieving well-defined objectives and training specific skills in accordance with the Vocational Training Standards of each qualification in the field of Tourism and alimentation.

At this stage, 472 students from different levels of study, in four Constanta Technological Lyceums participated and for exemplification, we chose to present in the paper the activities carried out in the 9th A grade (experimental) and 9th B grade (control) of the Technological High School „CA Rosetti” Constanta.

In order to carry out this research, the didactic activities took place in the high school's tourism laboratory, at the individual tables and at the ten computers.

The experimental class has a number of 24 students who know how to use the computer at mid-level. To successfully apply ICT in classroom, at the beginning of the 20142015 school year, the teacher suggested students to create a class account in the Google Drive application (https://drive.google.com), explaining its utility, usage and the benefits of using the application in school and outside the school etc.

https://www.easyclass.com/sections/73708/updates

\section{easygclass Acasă cursuri Grupuri Fiģierelemele Inbox}

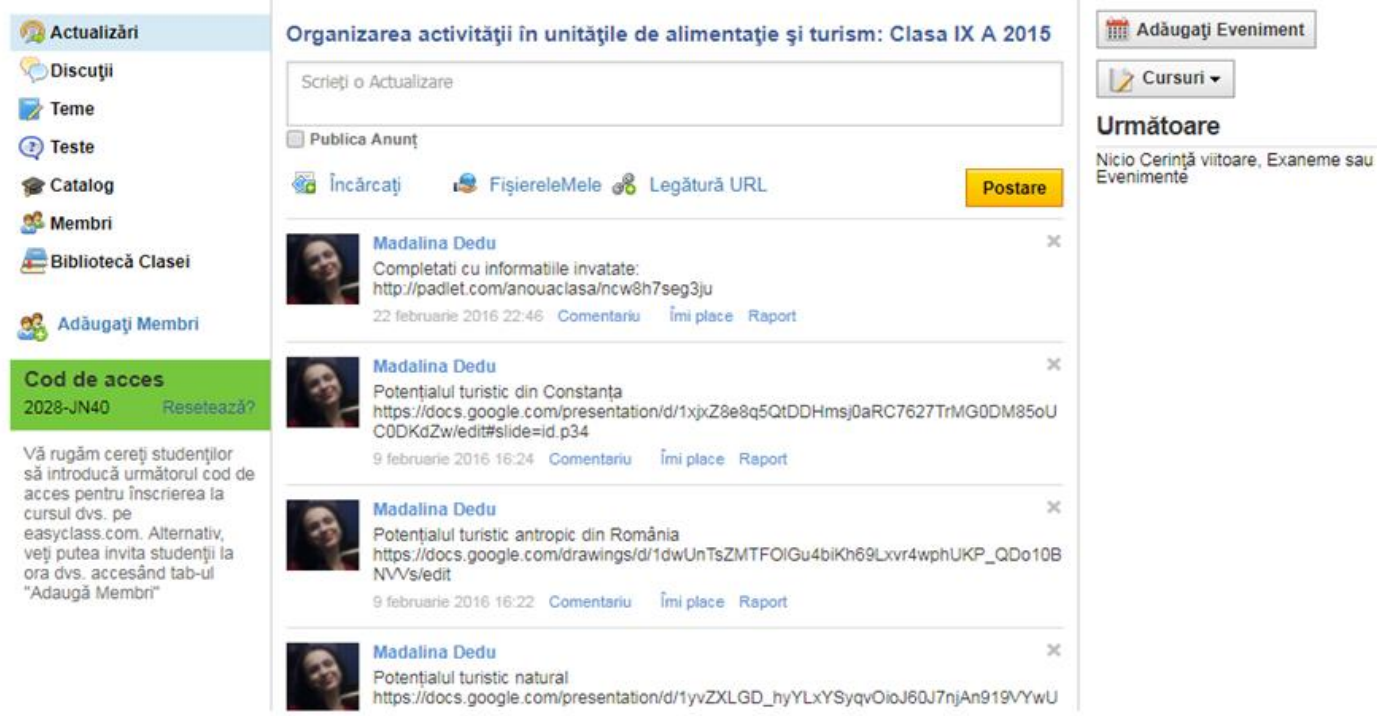

Figure 1 - Platform www.easyclass.com - 9th A grade, Technological High School „C.A. Rosetti” Source: Contribution of the authors. 
Also, the teacher familiarizes students with the educational platform www.easyclass.com, and they are guided to enroll as members of the virtual class already set up by the guidance teacher. (https://www.easyclass.com/sections/73708)

The 9 th $\mathrm{B}$ control grade has a number of 24 students who use classical and modern teaching methods in educational activities. following:

The didactical activities belong to the second module, the main features being the

Module II: Organization of the activity of food and tourism units

Unit of learning: Tourist potential

Unit of competence: Tourism potential

Specific competencies targeted: C1 - Informs customers about natural sights; C2 Informs customers about anthropic tourist attractions; C3 - Inform customers about the local tourist offer.

Skills derivatives: C1 - to define tourism potential; C2 - să to identify the components of tourism potential; C3 - to characterize the natural and anthropic tourism potential; C4 to identify the components of the natural and anthropic tourism potential; C5 - to characterize the natural and anthropic tourism potential of Romania; C6 - to characterize the anthropic tourism potential of Constanţa.

The activities carried out in the experimental $9^{\text {th }}$ A grade are shown in Table 1. and the activities carried out in the control $9^{\text {th }} \mathrm{B}$ grade are found in Table 2.

Table1. The project of the learning unit „Tourist potential”, 9th A grade

\begin{tabular}{|c|c|c|c|}
\hline No & Content (lessons) & Learning activities using ICT methods & Obtained results \\
\hline 1. & $\begin{array}{l}\text { Natural tourist objectives } \\
\text { in Romania: } \\
\text { - Lesson of transmitting } \\
\text { and acquiring new } \\
\text { knowledge }\end{array}$ & $\begin{array}{l}\text { - transmitting the knowledge by presenting } \\
\text { new theoretical information on the natural } \\
\text { tourist potential in electronic format using } \\
\text { Google Slides [1]; } \\
\text { - fixing new knowledge by leading students to } \\
\text { discover new information on natural tourist } \\
\text { sights in Romania using the Google.com search } \\
\text { engine and completing the presentation from } \\
\text { the previous stage [2], [3], [4]. }\end{array}$ & $\begin{array}{l}\text { - understanding } \\
\text { and assimilation of } \\
\text { definitions; } \\
\text { - completing the } \\
\text { Google Slides } \\
\text { presentation with } \\
\text { natural sights in } \\
\text { Romania }\end{array}$ \\
\hline 2. & $\begin{array}{l}\text { Anthropic tourist } \\
\text { objectives in Romania } \\
\text { - mixed lesson }\end{array}$ & $\begin{array}{l}\text { - refreshing previously acquired notions by } \\
\text { completing a questionnaire created with the } \\
\text { Google Form app; } \\
\text { - transmitting new knowledge about anthropic } \\
\text { tourism potential with Google Slides [5]; } \\
\text { - fixing the new knowledge by selecting } \\
\text { important anthropic tourism objectives in } \\
\text { Romania and creating virtual posters with } \\
\text { Google Drawings [2], [3], [6] }\end{array}$ & $\begin{array}{l}\text { - understanding } \\
\text { and acquiring new } \\
\text { notions; } \\
\text { - virtual posters } \\
\text { representing } \\
\text { various anthropic } \\
\text { tourist attractions } \\
\text { in our country }\end{array}$ \\
\hline 3. & $\begin{array}{l}\text { Anthropological tourist } \\
\text { objectives in Constanta } \\
\text { - a lesson of consolidation } \\
\text { of knowledge }\end{array}$ & $\begin{array}{l}\text { - fixing and consolidating knowledge by } \\
\text { creating a slide show with Google Slides on the } \\
\text { anthropological tourism potential of Constanta } \\
\text { [7] }\end{array}$ & $\begin{array}{l}\text { - electronic } \\
\text { presentation of the } \\
\text { main tourist } \\
\text { attractions } \\
\text { Constanta }\end{array}$ \\
\hline
\end{tabular}


Source: Authors' own research.

Table2. The project of the learning unit „Tourist potential”, 9th B grade

\begin{tabular}{|c|c|c|c|}
\hline No. & Content (lessons) & $\begin{array}{l}\text { Learning activities using traditional and } \\
\text { modern methods }\end{array}$ & Obtained results \\
\hline 1. & $\begin{array}{l}\text { Natural tourist objectives } \\
\text { in Romania: } \\
\text { - Lesson of transmitting } \\
\text { and acquiring new } \\
\text { knowledge }\end{array}$ & $\begin{array}{l}\text { - transmitting knowledge about natural } \\
\text { tourism potential through document sheets } \\
\text { shared to students, using traditional didactic } \\
\text { methods such as explanation, conversation, } \\
\text { reading with reference to the new information } \\
\text {-fixing the new knowledge by leading the } \\
\text { students to discover new information on } \\
\text { natural tourist objectives in Romania with the } \\
\text { help of books and magazines from the tourism } \\
\text { laboratory. }\end{array}$ & $\begin{array}{l}\text { - understanding } \\
\text { and assimilation of } \\
\text { definitions; } \\
\text { - making posters } \\
\text { with images of the } \\
\text { Romanian tourist } \\
\text { objectives drawn } \\
\text { from magazines or } \\
\text { drawings }\end{array}$ \\
\hline 2. & $\begin{array}{l}\text { Anthropic tourist } \\
\text { objectives in Romania } \\
\text { - mixed lesson }\end{array}$ & $\begin{array}{l}\text { - updating previously acquired notions by } \\
\text { filling in the worksheet; } \\
\text { - the transmission of new knowledge about the } \\
\text { anthropic tourism potential with the help of } \\
\text { the manual and of the explanations of the } \\
\text { teacher; } \\
\text { - fixing the new knowledge by selecting images } \\
\text { from magazines with important anthropic } \\
\text { tourist attractions in Romania and creating } \\
\text { posters }\end{array}$ & $\begin{array}{l}\text { - understanding } \\
\text { and acquiring new } \\
\text { notions; } \\
\text { - posters } \\
\text { representing } \\
\text { various anthropic } \\
\text { tourist attractions } \\
\text { in our country }\end{array}$ \\
\hline 3. & $\begin{array}{l}\text { Anthropological tourist } \\
\text { objectives in Constanta } \\
\text { - a lesson of consolidation } \\
\text { of knowledge }\end{array}$ & $\begin{array}{l}\text { - consolidating knowledge by discovering the } \\
\text { tourist objectives in Constanta city inside } \\
\text { promotional leaflets and completing } \\
\text { worksheets. }\end{array}$ & $\begin{array}{l}\text { - filling in the } \\
\text { worksheets }\end{array}$ \\
\hline
\end{tabular}

PICBE | 295

Source: Authors' own research.

\section{The post-experimental stage}

The third stage of the research involved the measurement of the dependent variables in the two experimental and control samples, by applying the posttest containing the similar samples, comparing the initial data with the final ones and determining the relevance of the differences obtained, which led to confirmation or refutation of research assumptions.

The dependent variables of the research were:

- training and development of specific skills,

- degree of understanding and assimilation of specialized content.

In order to measure these two dependent variables, teachers applied tests for assessing the knowledge acquired by pupils in the experimental and control classes as a result of each unit's learning included in the sample. These tests included items of different types and were formulated according to the specific competencies and derived competences of each unit of learning, following the degree of their formation and development at the students of the two samples. 
In the following, we present the results at the post-test obtained by the students from the 9th A and B grades, from the Technological High school „C.A. Rosetti” of Constanta, participants in the research.

The post-test for the 9th grade was structured in two parts, and each part contained three items of different types. He pursued:

- the level of understanding and conscious assimilation of the notions of natural and anthropic tourism potential, asking students to say what they understand by the two notions, to identify examples of tourism resources of each type, to specify the geographical areas in which different tourist attractions are;

- training and developing specific skills, asking students to inform tourists in writing, within a structured essay, on the elements of the touristic and natural potential in Constanta County.

Table 3. Results at posttest, 9th grade, Technological High School „C.A. Rosetti”

\begin{tabular}{|c|c|c|c|c|c|c|c|}
\hline \multirow[t]{2}{*}{ GRADE } & \multirow{2}{*}{$\begin{array}{c}\text { STUDY } \\
\text { DISCIPLINE }\end{array}$} & \multirow{2}{*}{$\begin{array}{l}\text { No. of } \\
\text { students } \\
\text { enrolled }\end{array}$} & \multirow{2}{*}{$\begin{array}{l}\text { No. of students } \\
\text { who have } \\
\text { taken the test }\end{array}$} & \multicolumn{4}{|c|}{ SCORES } \\
\hline & & & & $<5$ & $5-6.99$ & $7-8.99$ & $9-10$ \\
\hline $\begin{array}{ll}9^{\text {th }} & \text { A } \\
\text { grade } & \end{array}$ & $\begin{array}{l}\text { Tourism and } \\
\text { alimentation }\end{array}$ & 24 & 24 & & 1 & 10 & 13 \\
\hline $\begin{array}{l}9^{\text {th }} \quad \text { B } \\
\text { grade }\end{array}$ & $\begin{array}{l}\text { Tourism and } \\
\text { alimentation }\end{array}$ & 24 & 24 & & 9 & 11 & 4 \\
\hline
\end{tabular}

Source: Authors' own research

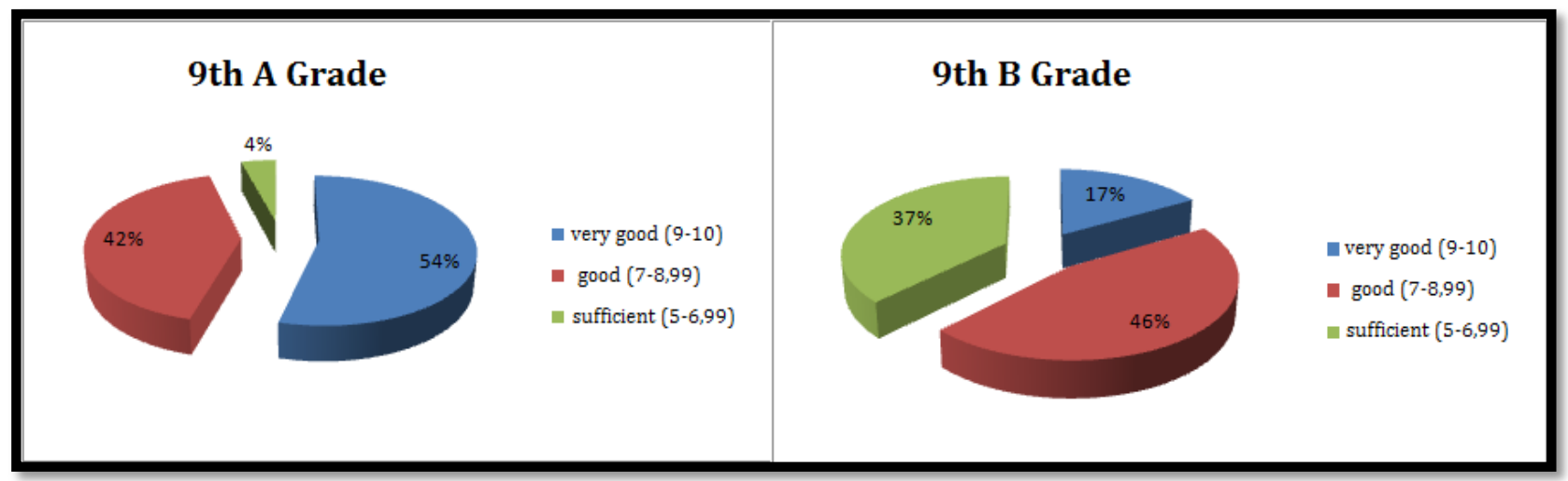

Figure 2 - Posttest results, 9th Grades, Technological High School „C.A. Rosetti”

Source: Authors' own research.

Following the post-test at the 9th grade of the Technological High school „C.A. Rosetti" Constanta, the next results were obtained:

- In the 9th A grade, out of a total of 24 students, $54 \%$ received scores of 9 and 10 , respectively the Very Good score, $42 \%$ obtained grades 7 and 8 , respectively the Good, and $4 \%$ grades 5 and 6, with Sufficient;

- In the 9th B grade, out of a total of 24 students, $17 \%$ received scores of 9 and 10, respectively the Very Good score, $46 \%$ obtained grades 7 and 8, respectively the Good şi $37 \%$ grades 5 and 6, with Sufficient. 
Similarly, all other classes were investigated, the results being similar.

\section{Conclusion}

Based on the study, we noticed that the pupils in the experimental sample obtained better results than those in the control sample, thus confirming the assumptions initially established. At the same time, the pupils of the experimental sample had a better evolution than the initial level of knowledge.

In order to be able to say that an activity has been successful, it is necessary, at the end of it, to compare the final results obtained with the proposed objective at the beginning and to determine whether and to what extent there is equality between them, ie whether the purpose of the activity has been reached.

The aim of the research was to highlight the effectiveness of the use of Information and Communication Technology as a teaching, learning and evaluation didactic method for improving the educational process within the high schools. Analyzing the initial objectives arising from the research goal and the results obtained in the end, we can draw the following conclusions:

01: Developing the specific skills to the fullest extent by using ICT methods

The study results obtained by statistical interpretation show that the use of ICT methods and tools in the didactic activity has led to the formation and development of specific skills of pupils in the experimental sample to a greater extent than the use of classical methods in the instructional process with pupils in the control sample.

Given that the other factors that can influence learning have been kept, to a large extent, constant, we can say that the evolution of school results on competency training and development is mainly due to the use of ICT methods and tools during the pedagogical experiment.

O2: Expanding the knowledge assimilated by students within the hours of tourism

Starting from an approximately equal level of knowledge, it can be noticed that all pupils who participated to the research have widened their area of specialized knowledge, but those in the experimental sample have assimilated new knowledge to a greater extent than those in the control sample, by using ICT methods and tools in their activities.

O3: Improving school performance in specialized disciplines measured by the results to school contests

The school performance refers to the scores obtained to the pedagogical tests applied in the posttest and retest phases of the research, and we observe that these increased comparing to the results obtained in the pretest stage, the pupils in the experimental sample having higher school performance than those in the control sample.

04: Increasing student motivation for active participation in tourism lessons

This objective was measured with the help of observation sheets supplemented by the teachers during the curricular activities, which contain information about the students' behavior in these activities. Based on their analysis, we found that the students in the experimental sample are more attracted to the actions taken during the teaching-learning process, actively participating in the educational activity by asking questions and answers, by fulfilling the various assigned tasks, by solving the themes, working with the coordinating teacher and with colleagues, using of ICT methods and tools indicated, etc.

05: Reducing absenteeism at tourism classes 
Monitoring absenteeism was achieved by counting absences from the catalog to the specialty modules. We can say that the students in the experimental sample recorded a number of slightly lower absences than those in the control sample, but this can be due also to other factors, apart from the teaching methods used in the lessons, factors that cannot be controlled or influenced by students or teachers.

Analyzing the results of the pedagogical experiment, we were able to observe a better evolution of the experimental sample compared to the control sample, the school performance obtained by it being due to the use of ICT methods and tools in the teaching and learning of information in the tourism modules, the others factors that could have influenced this evolution were kept constant for both samples.

Finally, we can conclude that the purpose of the research has been largely achieved, demonstrating that the use of Information and Communication Technology as a didactic teaching, learning and evaluation method is effective for improving the instructionaleducational process within the Tourism high schools.

\section{References}

Brezeanu, I., \& Gorghiu, G. (2012). Particularities of CMS integration in e-learning systems. National Conference on Virtual Learning Modern Technologies in Education and Research, Bucharest, 84-90.

Constantin, L.V., \& Dinică, L. (2006). Efficiency of ICT use in the instructive-educational process. National Conference on Virtual Learning, Bucharest, 297-304.

Ghinea, V. M., Dima, A. M., \& Hadad, S. (2017). EXCELLENCE MODEL FOR SUSTAINABLE CONVERGENCE IN THE EU HIGHER EDUCATION. Amfiteatru Economic, 19(11), 1107-1122.

Government of Romania, Ministry of Communications and Information Society. (2012). Using ICT for Educational Activities - Guide for Teachers. Knowledge based economy. Retrieved from www.marinpredapitesti.ro/wp-content/uploads/2013/11/ghidpentru-profesori.pdf.

Hadad, S. (2017), "Strategies for developing knowledge economy in Romania", Management \& Marketing, Challenges for the Knowledge Society, 12(3), 416-430. DOI: 10.1515/mmcks-2017-0025.

Mocanu (Dedu) E. M., \& Deaconu, A. (2017). The use of Information and Communication Technology (ICT) as a teaching method in Vocational Education and Training in tourism, Acta Didactica Napocensia, 10(3), 19-34.

Radu, C. (2014). Emotional Intelligence - How do we motivate our students?, Procedia Social and Behavioral Sciences, 141, 271-274.

Radu, C. (2016). Motivating Students - How Great Teachers Should Be?, Proceedings of MAC-ETL 2016 International Conference, Prague, Czech Republic.

Tinio, V. L. (2003). ICT in Education, UNDP-APDIP. Retrieved from http://wikieducator.org/images/f/ff/Eprimer-edu_ICT_in_Education.pdf.

Vandenbroucke, F. (2007-2009). Competencies for the knowledge society. ICT in education initiative, Flemish Minister for Employment, Education and Training. Retrieved from https://www.scribd.com/document/7382723/Competencies-for-the-KnowledgeSociety.

WCCE. (2005). http://www.sbs.co.za/wcce2005/. Retrieved on 2015 
https://docs.google.com/presentation/d/1yvZXLGD_hyYLxYSyqvOioJ60J7njAn919VYwUZp T39E/edit?usp=sharing.

http://www.ghidvideoturistic.ro/ghid-turistic/atractii-turistice.asp

https://docs.google.com/presentation/d/1yvZXLGD_hyYLxYSyqvOioJ60J7njAn919VYwUZp T39E/edit?usp=sharing https://docs.google.com/presentation/d/1S3P5rDEzCnVroYEcFLjQSeN6iTY67s46y9gCgJB mgXM/edit?usp=sharing

https://docs.google.com/drawings/d/1dwUnTsZMTFOlGu4biKh69Lxvr4wphUKP_QDo10B NVVs/edit?usp=sharing

https://docs.google.com/presentation/d/1xjxZ8e8q5QtDDHmsj0aRC7627TrMG0DM85oU CODKdZw/edit?usp=sharing 